\title{
Esther Summerson's Biblical Judgment: \\ Queen Esther and the Fallen Woman in Bleak House
}

\begin{abstract}
In criticism to date, the intertextual link between Esther Summerson and the biblical Queen Esther has been explained as one that invokes "womanly virtue". By drawing on the meanings that had accumulated around the name "Esther" in the Victorian period, this article argues instead for Queen Esther's significance as a sexual transgressor. Manifested in the protagonist's illegitimacy, sexual transgression makes Esther Summerson a quilting point for layers of biblical allusion to the fallen woman and judgment within Bleak House. Linked to John 8's woman caught in adultery and the novel's repeated invocation of apocalyptic judgment, attention to Queen Esther reveals the novel's negotiation of different kinds of judgment to avert condemnation of the fallen woman whilst underlining the need for the denunciation of social ills.
\end{abstract}

In Bleak House (1852-3), names are not arbitrary. Blatantly and subtly, names communicate essential aspects of individual characters. Miss Flite desires freedom and escapes into madness, Smallweed is the minor yet strangling tare of capitalism and Nemo has self-designated his non-existence. Where Miss Summerson brings light and life wherever she goes, her forename Esther would have been equally, and immediately, meaningful to a Victorian biblically saturated audience. 
Dickens not only knew his Bible well but engaged with it in complex and profound ways, as recent scholarship demonstrates. ${ }^{1}$ By his own admission, he included the Bible within his novels "unostentatiously," likening his biblical allusions to Jesus' ideal, humble devotees, who "all arise and wash their faces, and do not appear unto men to fast." 2 Yet Dickens's biblical references are apparent to the biblically knowledgeable reader. The Book of Esther, the least obviously religious of biblical stories, would appeal to the notoriously unorthodox Dickens. Marginal to the Christian canon, Esther was seldom referenced in nineteenth-century religious works. Nonetheless, Esther characters in literature proliferated from the mid-century onwards and direct references to Queen Esther appear in the journals Dickens edited. ${ }^{3}$ First published in Dickens's journal, Household Words, Elizabeth Gaskell's Cranford draws on Esther's act of mediation as its character Miss Matty compares her mother to Queen Esther and her father to King Ahasuerus. ${ }^{4}$ In another of Dickens's journals, All the Year Round, we find the heroine of Charles Hamilton Aidé's “The Mystery of the Moated Schloss," Magda, again invoking the queen's petition to the king in a prayer for courage. When Magda rises from prayer, she sees a painting depicting scenes from the story of Esther and it is perhaps the story's violent overtones that are gestured to when Magda's night-time terrors are augmented by her seeing the characters Esther, Ahasuerus and Haman descending out of the painting towards her. These allusional references to Esther are brief gestures towards the story that work in and through intimate knowledge of it, but beyond testifying to Dickens's probable familiarity with the story, they offer little information about how he understood Esther or her story. ${ }^{5}$

Queen Esther's significance for Esther Summerson is widely assumed in Dickens scholarship, which includes lengthy analyses of the link that is predicated primarily on 
Inspector Buckett's and Esther's own references to queenship. ${ }^{6}$ The relation is assumed by critics too numerous to list and Queen Esther is overwhelmingly read, as Saskie Lettmaier notes in passing, as the "biblical pillar of womanly virtue."7 The assumption of virtue is one that my own article seeks to contest in revealing that the novelistic Esther primarily signifies sexual transgression as the testing ground of theologies of forgiveness and grace that suspend condemnation.

In order to unearth the complex significance of the name Esther in the Victorian period, this essay opens with a comparison of biblical allusion with metaphor and allegory, the two modes of interpretation most commonly associated with Dickens's novel. It then suggests a model for understanding biblical allusion via an analysis of two in-depth discussions of Esther Summerson and Queen Esther by Janet L. Larson and Gary Watt. These critics demonstrate two common approaches to biblical allusion: consideration of her religious tradition and text-to-text comparison. To understand the allusion to Queen Esther, this essay turns to what Dennis Walder has called the "relevant contemporary context of belief". While Walder argues this context is most "sharply evidenced" in religious periodicals, a key argument of this article is that the relevant context for understanding Queen Esther's cultural meanings is evidenced in literary works of the period. ${ }^{8}$ Yet literary works of the mid-nineteenth century demonstrate a surprisingly consistent set of meanings: a hitherto neglected understanding of Queen Esther as a heroic fallen woman, who both suspends and passes judgment, that enables a new interpretation of Esther Summerson and Bleak House.

The novel's abundant use of metaphor encourages the reader into a specifically deciphering frame of mind. ${ }^{9}$ The opening's focus on London's fog and mud are well known 
for their success at doing the work of metaphor in drawing together two dissimilar things to reveal meaning: that the obfuscatory legal system is slippery, disorientating and deadly. Whilst Dickens invites a metaphoric interpretive frame, to read into "signs and wonders" (the title of chapter 5), he is also clearly suspicious of interpretation's excesses. Allegory, embodied as a painted “Roman" on Tulkinghorn's ceiling, presents an image of interpretive promiscuity via his pointing finger, which, through an assumed optical illusion, gestures to the object most significant to the viewer. At times the Roman motions towards Tulkinghorn, at others to his visitors, a dead body and a stain of blood. Allegory, as Dickens playfully recognizes, may be applied to almost any object of the interpreter's choosing, a license most notoriously seen in the more salacious interpretations of the biblical Book of Revelation's mysterious symbols. At this time, signs of the end of world were applied liberally so that it was not unusual to use the label antichrist to signal theological opposition to an individual. ${ }^{10}$ Dickens warns that placing too much meaning in an inherently polysemous code, like Allegory's, "makes the head ache." Indeed, the production of such headaches "would seem to be Allegory's object always" (ch. 10, 119). Where metaphor encourages a carrying over of a limited range of traits and allegory points to nothing specific, then, biblical allusion invokes both a story and that story's larger and extended context. Reference to a biblical source therefore complicates the more straightforward indexical functioning of names and metaphor in the novel. The name Esther points not to linguistic connotations, but intertextual complexity because it pushes meaning outside of the novel to the space between it and another equally intricate narrative and its interpretations. In other words, reading biblical allusion requires not just knowledge of the Bible but its specific reception. 
As already noted, in the case of a marginal book such as Esther, retrieval of its wider cultural reception is difficult. Victorians would undoubtedly be familiar with the Book of Esther as an Old Testament story of providence, threat and triumph. Rarely preached on (in comparison not only to the New Testament, but much of the Old Testament too), it is the only biblical book not to mention God and so its story offers oblique connections to faith. Set in the ancient Persian Empire, the story tells of the redemption of the Jewish diaspora. When Queen Vashti is banished for disobedience, the king gathers the empire's virgins, from whom Esther is chosen as the new queen. Her Jewish identity is kept secret and becomes strategically essential when the malevolent courtier Haman orchestrates a law ordering the destruction of the Jewish population. Through complicated manoeuvres, Esther petitions the king, denounces Haman, and Esther and her uncle Mordecai send out laws allowing Jewish self-defence and a second set of edicts ordering festive celebration.

The bare plot of the Esther story is inadequate to unearth what this story meant to the Victorians. It is difficult to know, for example, whether the Esther in this story is heroic or timid, passive or active. The understanding of such stories depended on their stated or implicit application in sermons, commentaries, paintings, and stained glass windows (Esther appears, for example as Flora MacDonald in St Columba's Episcopal Church, Portree, Isle of Skye). In any cultural setting the Bible enters a web of meaning caught up with authority, moral force and fraught with debate. Larson and Watt both attempt to decipher this web of meaning and present the two most sustained modern analyses of Esther Summerson's relation to the biblical queen, useful here primarily for their different methodological approaches to biblical allusion. 
For Watt, writing for a law journal, Queen Esther is significant as a figure of equity, a concept which links fore and surname as Dickens has created through her a "dynamic contrast between the documentary obscurity of the law and clarity of daylight."11 Watt argues that, as Queen Esther averts the deathly blow of Haman's edict, so Esther Summerson repeatedly softens the blow of judgment on others, making her "a moderating influence to deflect the power of legal formalism from causing harm to the innocent."12 Esther enacts equity, then, through her personal influence that elevates the individual case above the deadly letter of the law. Watt presents a text-to-text comparison of the novel and biblical book by identifying thematic correspondences (aversion of deathly edicts in the Bible against legal rigidity and personal moderation in Bleak House), which are then potential sites for inferring meaning from the novel. In placing the texts side-by-side, Watt cautions that "we should not overstate parallels between these biblical tales and the story of Esther Summerson" and sticks to key thematic elements. ${ }^{13}$

Larson, in contrast, focuses on the importance of the Bible's exegetical tradition and draws on Catholic and Protestant writings to identify Esther as a type of the Church or Mary, identifying Esther with grace. Queen Esther's fairy tale mentality sheds light on Esther Summerson's propensity to evade harsh realities but it is ultimately an "inadequate subtext for Esther's 'progress'” and Larson heralds Job as the more "appropriate subtext."14 Job, which she identifies with law, provides a more fitting bleak, realist mode. Larson repeatedly draws on the Apocryphal "Additions" to Esther found in the Septuagint and Catholic Bible, so called because they add extra narrative elements to the canonical story including prayers and religious content. It was, as Larson helpfully points out, contained within the family Bible that Dickens owned. Dickens was well known for his theological 
opennesss, but, as Charles LaPorte expresses it, "most Victorian Protestants balked at these apocryphal and pseudepigraphical texts for their Papist affinities," referring to a common antipathy to Roman Catholicism that Dickens seemed to share. ${ }^{15}$ As Sue comments in Jude the Obscure about Jude's reading of the New Testament Apocrypha: "'twould alarm the neighbourhood." 16 The Additions to Esther are therefore an unlikely reference point for Dickens or his audience. The Apocrypha is useful for Larson because she can draw on its more psychological, romantic and fairy-tale Esther to the detriment of the sexually unorthodox Esther that, as will be discussed, Larson recognises yet dismisses. As we will see, the Esther of the Protestant canon is closer to the biblically authorised rebel, Job, than Larson's nonetheless brilliant reading allows.

Watt and Larson present two models for dealing with biblical allusion. Watt sets text against text with little reference to contemporaneous exegesis. Larson presents a wealth of exegetical commentary from Josephus to a sermon by Queen Victoria's chaplain, but draws on the Apocryphal Esther that is still at some distance from Walder's "relevant contemporary context of belief." Yet Larson also practices text-to-text comparison (albeit with the Apocryphal Esther) and both approaches underplay the complexity of how biblical allusion works in Dickens's novels. As Susan Colon's analysis of Dickens's use of parables eloquently demonstrates, his engagement with the Bible is highly complex. Norbert Lennartz suggests that Dickens

creates an intertextual montage to make us aware of the fact that Victorians preferred to think in terms of typology. In this respect, the modern Dickensian arks are symbolic vessels expressive of the hope that the diluvian torrents of modernity can eventually be checked or at least diminished. ${ }^{17}$ 
Typology works through reference to a "type", a character, object or story, which provides a model or ideal that is then fulfilled or copied in its antetype. A familiar mode of reading for the Victorians, as George Landow explains at length in his study, Victorian Types, Victorian Shadows, typology is modelled by Lennartz in the quotation above in which Noah's ark is a model of hope fulfilled in the antetype of the novel itself as a vessel of hope. Such complex invocation of the Bible depends on audience familiarity not merely with biblical stories but with the hermeneutical acrobatics associated with Bible reading. Even Lennartz's model of typology is a little rigid in its identification of mere replication. The Bible, and characters in particular, would not only be approached in terms of typology. A genres like the parable suggest more complex, yet familiar, ways of reading the Bible that work obliquely, or "parabolically" to use J. Hillis Miller's term, in order to gesture towards the way that stories touch their subject in vague and indirect ways. ${ }^{18}$ It is precisely such sophisticated reading practices that Dickens seems to assume that his readers will employ when they read his novel.

In practice, readers of novels faced with biblical allusion would not pause to reread a biblical story or consult a commentary. Instead, they would have a version of Esther at hand, received through everyday interaction with the story through sermons, artwork, and for the studious, printed commentaries and sermons. Readers would first and foremost draw on associations attached to the name through social accretion. Mikhail Bakhtin uses the image of a ray of light to illustrate this accumulation of meaning ascribed to any, but for my purposes here to the biblical, word. The ray of light, in its attempt to reach its object, moves along paths "strewn with previous claims that slow up, distort, refract the intention of the word." ${ }^{19}$ On the way to its object - the signifier's path to the signified - it passes 
through atmospheric debris made up of the "alien words, value judgments and accents through which the ray passes on its way to its object."20 Bakthin's image illustrates a word's historical specificity, but importantly also the positive elements of language's sociality. The atmospheric debris is not a set of obstacles that distort, but, like dust in the sun's rays, such fragments make "the facets of the image sparkle."21 The name "Jezebel," for example, sparkles with connotations of sexuality and aggression without need for conscious or detailed recall of her story. Identification of a biblical name's social atmosphere is not about the deciphering of distorting accents and prejudices, behind which a pure meaning could exist, but the unearthing of what makes the image "sparkle", of what makes it meaningful and alive.

Tracing the social atmosphere of the name Esther is a complex project for readers who no longer exist within, or can even imagine, the theologically-infused atmosphere of Victorian Britain. Victorian readers would experience such an atmosphere as a set of immediate and intuitive associations. Tracing what Esther meant to her Victorian audience is especially difficult as it depends on inferring a larger picture from those few writings on Esther still extant from the time of Bleak House. These written texts are not the atmosphere that would surround the word "Esther", therefore, but point towards what this atmosphere would look like: they are partial elements of a larger whole. Patterns and assumptions can be traced from a small number of printed commentaries and sermons from the period and the preceding decades, but their full outworking becomes most obvious through attention to novels with characters named Esther.

The unconscious nature of such provocations does not preclude more active connections between two stories. Atmospheric connotations work alongside and provide 
the context for any specific text-to-text likenesses that the novel itself may encourage. These gestures and signposts to the biblical text depend less on general literacy and more on the reader's intuitive recognition. Although no exact reading experience can be assumed for any given reader, identification of a biblical atmosphere - the loose, cultural accretion of meaning still obvious today in names like Beelzebub or Jesus, for example - produces some predictable significances. This essay recovers this atmosphere in order to inform what the name "Esther" did or could mean to a Victorian audience. Any further textual comparisons can then be added to an already established context of meaning.

Whilst the Book of Esther would communicate to some a tale of court intrigue reminiscent of Joseph's story, or of the reversal of fates, like a Passover story, for anyone familiar with its theological reception, it would also signal trouble. Victorian writers seem peculiarly interested in the figure of Esther ${ }^{22}$ suggesting an appeal beyond the conventional feminine traits of mercy or piety associated with easier-to-recognise figures such as Mary. Esthers appear in some of the period's most studied and popular novels such as Elizabeth Gaskell's Mary Barton (1847), Nathaniel Hawthorne's The Scarlet Letter (1850), George Eliot's first novel, Adam Bede (1859) and her Felix Holt (1866), as well as Margaret Oliphant's Hester: A Story of Contemporary Life (1883), George Moore's Esther Waters (1894), and Mary Cholmondeley's bestselling Red Pottage (1899). Consideration of all of these novels is impossible in this forum, but those novels that pre-date Bleak House, which I discuss shortly, provide a rich resource for understanding the significance of the Esther figure.

Theological writings on Esther that survive offer more intriguing readings of the queen and her book than have so far been recognised by literary readings of Esther 
characters..$^{23}$ As already briefly discussed, the Esther story is hermeneutically, theologically and morally problematic, notorious within biblical scholarship. ${ }^{24}$ First, it is not a story of divine justice or providence - despite frequent devotional assertions to this end - but of divine absence, a problem that has been the forefront of discussion throughout its history. ${ }^{25}$ As anyone undertaking even a cursory investigation into the book would know, the earliest rabbinic commentaries and later theologians, such as Martin Luther, questioned its canonical status. ${ }^{26}$ As a weak point, Esther would most likely exacerbate the sense of threat to biblical integrity felt in the light of German Higher Criticism. Yet it is possible that the book's unorthodoxy is precisely what piqued novelists' interest. Its problematic, "wilderness" status suggests that, rather than preserving conservative models, Esther attracted those wishing to propose something new, something novel. ${ }^{27}$

Second, Esther is a book that is hard to assimilate to Protestant norms. Although Catholics solved the book's heterodoxy by reading it allegorically, with Esther acting as a type of Mary (both supplicating their king for the people), Protestants resisted Larson's identification of Esther as a type of the feminine Church or Mary and were reluctant to read a woman as a type of Christ. Of problematic theological use, the story of Esther was often promoted for its modelling of "good" feminine behaviour, the "chaste, modest, discrete" and "pious" woman promoted by evangelical commentary. ${ }^{28}$ As already mentioned, we find this virtuous Esther in Gaskell's Cranford (1851) in which the mother of Miss Matty is a Queen Esther in her gentle arbitration for her children, "for my mother was very pretty and delicate-looking, and my father looked as terrible as King Ahasuerus."29

Yet, commentaries that push forward this docile figure also reveal, after very little inspection, a troublesome woman. To begin with, Queen Esther defies feminine norms of 
passivity in her heroism. Some commentators femininized such heroism as an inferior form of self-sacrifice, aligned with "sorrow, duty and love." ${ }^{30}$ For example, the Scottish Presbyterian minister, Thomas M'Crie, in his Bible commentary of 1838 identified her uncle Mordecai as the hero with Esther merely the brave yet subservient adjunct to his cause. But many did position Esther as a heroic model for England, a type for its female sovereign in both Elizabethan and Victorian periods, but also often its male parliament and its people. ${ }^{31}$ In the Victorian period this reading of Esther proliferated perhaps because, through aligning the Book, albeit tangentially, with a Christ-like heroism, Esther's likeness to Mary was weakened. George Lawson, Chair in Theology at the Association Session (Burgher) Church of Scotland, in 1804, promoted Esther as "the honoured instrument of [the Jews'] deliverance," even though he minimized her contribution: "she will have no reason to be proud," he warned and valued her "timidity" and "humility and modesty." 32 Despite these qualifications, for this dour Westmorland vicar, "her name shall live to the latest posterity in the records of those heroes and heroines who 'wrought righteousness, escaped the edge of the sword, out of weakness were made strong, and turned to fight the armies of the aliens."'33 Lawson here applied to Queen Esther a subsection of Hebrews 11 that praises only male heroes, aligning Esther implicitly with masculine versions of faith and heroism.

More specifically, Esther was celebrated as a deliverer. Whereas Lawson, above, identified the deliverance as God's, with Esther acting as his instrument, the lack of religious referent in the canonical Esther prioritises human agency. In the hugely influential Thomas Scott commentary (1827-), Esther was presented as the heroine, "advanced to her present dignity, on purpose to be the deliverer of her nation in this 
perilous crisis" and Scott, unusually, approached her as a type of Christ's self-sacrifice. ${ }^{34}$ Esther's sacrifice as a "deliverer" was therefore more often heroic than dutiful or submissive in conventionally feminine modes.

The Esther type as heroic deliverer emerged most strongly in literary form early in the nineteenth century in Walter Scott's The Heart of Midlothian (1818) with the explicit identification of the heroine, Jeanie, as an Esther figure. Jeanie attempts a walk from Edinburgh to London in order to petition the king for the life of her sister who has been accused (wrongly) of child murder. Whilst not named after her biblical counterpart, Jeanie speaks to (her soon to be fiancé) Reuben of her fears about the court:

Nae doubt their claiths will be very grand, wi' their crowns on their heads, and their sceptres in their hands, like the great King Ahasuerus when he sate upon his royal throne fornent the gate of his house, as we are told in Scripture. But I have that within me that will keep my heart from failing, and I am amaist sure that I will be strengthened to speak the errand I came for. ${ }^{35}$

By naming the king from the Esther story, Jeanie positions herself in an Esther role to invoke the strength she needs to petition for her sister's life. Jeanie is an exemplary Esther because she succeeds not only in persuading her monarch to grant her request (Jeanie obtains an audience with the queen), but in delivering her sister from death. The authorized Esther-figure of the submissive, dutiful, loyal petitioner, the traditional Marytype that critics so often invoke, is inadequate for Jeanie, although in her piety she is, undoubtedly, all these things. She is instead invoked as a "deliverer," echoing theological writings on Esther. In Scott's novel, then, what makes Jeanie identifiable as an Esther-figure is delivery of Effie, underlined by her father's tautological response to her act: "If ever a 
deliverance was dear and precious, this [...] is a dear and precious deliverance" (ch. 39, 383).

More troublesome for religious readers, but clearly appealing to novelists, is Queen Esther's sexual transgression, a trait that Larson recognises in Queen Esther's “sexual charms," but dismisses as one of many "striking contrasts" between Esther Summerson and Queen Esther. ${ }^{36}$ To choose his new queen, the king gathers together the virgins of the kingdom and he makes his choice after spending a night with each woman. Not only is Esther a member of the harem before she is made queen, but an apparently talented one. Esther's unorthodox sexuality haunts the tradition from its very beginning and even coy nineteenth-century commentators reveal concerns over Esther's premarital sexual encounter with the king. Alexander Whyte in his entry on Esther in his Bible Characters series of 1896 may veil the unseemly but certainly does not extinguish it: "I shall leave part of the unsavoury story veiled up in all the restrained and dignified language of the sacred writer," he states. As Michel Foucault has famously argued, what may appear as Victorian censoriousness was merely a form of compulsion to speak about transgression and desire. $^{37}$

While references to Esther in religious writings were few, they consistently attend to Esther's problematic sexuality. The Irish Baptist Minister, Alexander Carson (minister at Tubbermore, popular writer, and recipient of two American honorary degrees) in 1835 stated that Esther was "provided [...] for the bed of Ahasuerus" and insinuates: "But does the Holy One approve of this connexion?" (21), calling it her "vile prostitution." 38 For the influential and moderate Thomas Scott, Esther has "present dignity" and yet is labelled a concubine. ${ }^{39}$ Thomas M'Crie, a Scottish Presbyterian, similarly notes that Esther is "raised 
to the bed of Ahasuerus and the crown-royal," and like others claims she is "chaste, modest, discrete" and "pious," an assertion contradicted by his lingering description of harems as "gilded prisons in which the victims of Asian voluptuousness are immured." 40 That Esther's virtues include her sexuality for all of these writers destabilizes the coupling of femininity with chastity. Esther's sexuality sets her at some distance from the virginal Mary, with whom she is often conflated, and suggests that authors who invoke her do so to destabilize the seemingly paralysing formula of the irredeemable fallen woman. The significance of Esther's sexuality appears most forcibly in literary form and most obviously in Gaskell's Esther Barton, the sister-turned-prostitute in Mary Barton (1847), prefiguring by three years Hawthorne's notorious Hester Prynne of The Scarlet Letter (1850). In Gaskell's novel, Esther and Mary are sisters, their names invoking a pairing common in Catholic reception, as noted by Larson. Where Esther represents the cold hand of Old Testament law, Mary is a symbol of New Testament grace. Esther is seduced by a lover, left destitute with a small child, and resorts to streetwalking. Her sister Mary represents domestic stability and her daughter, also named Mary, further embodies grace as she is saved from a seemingly inevitable sexual fall.

Whilst Scott and Gaskell each emphasize in their novels one attribute of the Esther figure - deliverer or fallen - both narratives contain and overlap both character traits: where Jeanie is a deliverer, hers is a story of the fallen woman; while Esther Barton is a prostitute, her raison d'etre is deliverance of her niece. It is true that in bifurcating his Esther figure across Jeanie and Effie, these two identities - deliverer and fallen - do not coexist within one woman. None the less, as petitioner for the sexually transgressive, Jeanie-as-Esther gently complicates such categorisations. Effie’s “shame” extends to Jeanie 
because a woman's fall is, as Jeanie explains, "a blot that spreads to kith and kin" and she speaks of "a' my shame" despite her exemplary behaviour (ch. 27, 268). The influence works in both directions and Jeanie's virtues seep into our understanding of Effie through the close bond of sisterhood. It is also encouraged by the novel's overarching narrative invocation of doctrines of forgiveness, incarnation and atonement which draw on identityblurring theologies that were central to Victorian orthodoxy, in which one person stands in for another: Christ became sin as humans become blameless (2 Cor. 5.21).

The invocation of the characteristics of fall and deliverance are obviously a challenge to the link between morality, good action and chastity. The Esther-figure therefore becomes one that presents a challenge to orthodox femininity. Of especial interest to a reading of Bleak House is the fact that characters called Esther in The Heart of Midlothian, Mary Barton and the Scarlet Letter all present the fallen woman in a vulnerable relationship to law, alluding to Queen Esther's writing of edicts. Scott's novel makes much of the law that criminalizes the unmarried mother through presumption of guilt. In Mary Barton, Esther Barton is doubly subject to unjust laws: her brother-in-law, John, uses Christian theologies of law and judgment against her and the juridical system presumes guilt. John's rejection of Esther's petition is prompted by the upset she caused his now dead wife: "at the judgment day she'll rise, and point to thee as her murderer" he reprimands. When John throws Esther down, a policeman arrives not to protect her but to take her to the "lock-ups for the night." ${ }^{41}$ There, she laments over her niece Mary ("Who will save her?") and in the morning an unfair law thwarts her attempts to deliver her niece: "It was a clear case of disorderly vagrancy, and she was committed to prison for a month." 42 In the Scarlet Letter religiously infused law judges Hester Prynne and criminalizes her 
adultery. All three novels pre-empt the interest in the fallen woman and law that will become central to my reading of Bleak House.

Critics who recognise Queen Esther's significance for Bleak House have disregarded sexual transgression, perhaps because Esther Summerson is more obviously a figure of piety and, as an illegitimate child, her transgression is inherited. She is an indirect symbol of fallenness, much as Pearl and the scarlet letter are interchangeable and as Effie Deans's child is the "sign of $[\ldots]$ shame" $(20,205)$. Esther is marked by shame in a childhood written by a judgmental godmother, as I will discuss in more detail shortly, whose condemning attitude would be all-too-familiar to Dickens's readers. Literary depictions of the bastard child reveal, as Carolyn Kraus outlines, they were considered "embodiments of [the mother's] sin," an "emblem of transgression."43 Illegitimate children embodied punishment through deformity, chaos and lawlessness from the supposed unnaturalness of their birth. ${ }^{44}$ Esther Summerson is self-deprecating because she is a woman wrestling with society's condemnation of sexual transgression.

Whilst Dickens rejects hereditary shame by placing its expression in the mouths of Esther's repulsive godmother Miss Barbary and her maid Rachel, Esther's illegitimacy is nonetheless reiterated. But it is contestation of hereditary guilt that becomes an interpretive frame for Esther and the novel in its invocation of the wider themes of judgment, law and justice. Esther and her mother are paralleled in a way that suggests Dickens's purpose is to undermine attitudes towards inherited guilt. ${ }^{45}$ Esther carries her godmother's speech - "Your mother, Esther, is your disgrace, and you were hers" (ch. 2, 19) - into adult life. Rather than merely rejecting the notion of inherited guilt as irrational, Dickens invokes the biblical Queen Esther as a figure to complicate its logic. When Esther 
Summerson defends meritocracy against inherited guilt, she does so through reference to queenship: "I knew I was as innocent of my birth as a queen of hers; and that before my Heavenly Father I should not be punished for my birth, nor a queen rewarded for it" (ch. 36, 454-5). Because Queen Esther haunts the novel, a whole set of complications are invoked into this seemingly straightforward comparison of the low and high born. The biblical Esther, unusually for a queen, is low born and fallen. And it is Queen Esther's low birth that enables her "reward": her defence of the disparaged Jews depends on her beginnings in this marginal group. As a member of a harem, Queen Esther also serves to undermine assumptions of social status and Victorian conventions of sexuality. In light of the biblical intertext, the comparison does not merely indicate the transcending of birthright, but it blurs what the bastard-queen dichotomy assumes about sexuality and inheritance. The pure bastard and the fallen queen are oxymoronic yet conjoined in Queen Esther and the comparison places at a distance any grounds for moral judgment of the fallen woman or bastard child. Condemnation is deflected through an obscuring of categories and points of reference, a knot that invokes the intricacy of Chancery law and the associated, complex, theologies of Christian law and grace that Dickens engages with in the novel as a whole, as we will see. Dickens's reference to Esther sits alongside other biblical texts that also problematize the status of law: John's woman taken in adultery and apocalyptic references to the Day of Judgment. These texts layer up to produce a paralysing of the execution of the law in its condemnation of the fallen woman.

That it is important for the reader to engage with and refuse to judge Esther Summerson's illegitimacy is dramatized in her godmother's death. It occurs on an evening in which Esther partakes in a common Victorian practice intended to anchor the family in 
moral training: reading aloud from the Bible. Esther reads from John 8, a passage that becomes fused with and undercuts Esther's designated status as shameful when her godmother responds to it in a tellingly personal way. John 8 is the story of the woman "taken in adultery" (8.4), brought to Jesus to condemn. In her summary of her reading, Esther emphasizes the moment of Jesus's evasion of judgment: “how our Saviour stooped down, writing with his finger in the dust, when they brought the sinful woman to him." Esther invokes his refusal to judge: "So when they continued asking him, he lifted up himself and said unto them. He that is without sin among you, let him first cast a stone at her!" (John 8.7) Jesus here universalizes sin whilst simultaneously disallowing the sinful to execute condemnation. Esther's godmother interrupts this attempt to paralyse human condemnation with a counteracting verse to defend her own censuring attitude. She recites from Mark 13. 35-7: "Watch ye therefore! Lest coming he find you sleeping. And what I say unto you, I say unto all, Watch!" That this is a verse drawn from memory suggests its centrality to the godmother's theology. Her interruption stops the narrative before Jesus turns upon the woman's detractors to explicitly outlaw condemnation, a scene that would be understood to dramatize theologies of Christ's complex relation to law.

In the story, Christ's contemporaries presume that law can exist only in a binary form of presence or absence, force or removal, harsh condemnation or anarchic lawlessness. The King James Version summarizes the scene as a "snare," which the influential eighteenth-century commentator, Matthew Henry, explains is enacted when Christ's detractors wish to trap him into either "contradicting the law of Moses" into a form of licentiousness, or acting against "his own doctrine of mercy and pardon, if he should condemn her." The moment illustrates the tension that law presents: if upheld it produces 
an inhumane condemnation and inevitable death, but if dispelled it resigns humanity to an amoral system and presents God as licentious. Jesus succeeds, Henry comments, in that he "builds upon an uncontested maxim in morality, that it is very absurd for men to be zealous in punishing the offences of others, while they are every whit as guilty themselves." Henry's conclusion on the scene is to rhapsodize on Christ's mercy: "he is infinitely just and holy, none more compassionate than he to sinners, for he is infinitely gracious and merciful." It is this celebration of forgiveness that is the principal focus of Dickens's own version of the story in his Life of Our Lord, a rewriting of the gospels for his own children. ${ }^{46}$ Here, the woman is described for young ears as a "woman who had done wrong" 47 and Jesus perceives that the accusers "had come to make him say the law was wrong and cruel" (61) so they could then charge and kill him. Dickens's narrative repeats verbatim the biblical words (with added personal emphasis) from John 8.11: "neither do I condemn thee" (62). Although not as theologically complex as other contemporaneous treatments of the story, Dickens's version makes blatant the coexistence of definite judgment and an aversion to punishment. The woman's guilt is not questioned, her "guilt is undeniable," as Thomas Scott more clearly asserts. ${ }^{48}$ Jesus suspends condemnation only; law remains a guide for moral discernment. It is this sentiment of what most Christians would recognise as grace, manifest in forgiveness, from which Esther's godmother diverts attention. Jesus refuses the force of law not to embrace lawlessness, but, as Adam Clarke explained in his popular rendition of the gospels, Jesus "did not enter at all juridically into the business." ${ }^{99}$ There is a difference between judgment, a measuring of guilt or innocence against a legal framework, and condemnation, the application of law's penalty or punishment, a "juridical" response, 
which is vital to the story in John and to the narrative of Bleak House. Judgment and condemnation are separated and the latter overwritten in acts of forgiveness.

The relating of this story and her godmother's death pre-empts Esther's move from her godmother's house, associated with Mark 13's attitude of surveillance and judgment, to a man who refuses to judge. When Esther and John Jarndyce first speak of her history, Jarndyce explicitly declares Esther innocent (ch. 17, 213). Indeed, Jarndyce is a character who not only shies away from condemnation but finds judgment of others viscerally repulsive. The infamous East wind, that Jarndyce blames for his bad humours, represents not the difficulties of life, but specifically Jarndyce's feeling of discomfort when he is prompted to negatively judge other people. Esther observes: "the source of his pleasure was the goodness which was tortured by condemning, or mistrusting, or secretly accusing anyone" (ch. 6, 74).

Coupling the biblical reference to Queen Esther with John 8, Dickens produces a rich picture of the sinful woman for whom judgment's move into condemnation is suspended. Queen Esther has a compromised past in the king's harem, but she is celebrated for saving her people: her deliverance overwrites her suspect sexuality. The woman taken in adultery may be condemned by religious leaders but judgment is overwritten by Jesus' universalizing of sin and preference for mercy. The reference to John 8 underlines the strange relation between law, justice and judgment already discussed in which law is not negated in the diverting of condemnation. Watt explains the workings of law in Esther's story: "The process was equitable - not destroying the first law, but moderating its force."50 But Queen Esther's significance is more profound than Watt's localization of her influence allows. For Watt Esther is a figure of moderation, where equity is understood as "closely 
akin to Aristotle's notion of epieideia, which does not seek to overthrow general rules but seeks to modify them by resisting their unjust application in individual cases." ${ }^{21}$ In the light of John 8, Queen Esther indeed moderates the general principle of neutralizing the force of law to punish.52 The nexus of the fallen deliverer Queen Esther, the woman taken in adultery and the illegitimate Esther Summerson focuses more specifically on averting condemnation, not denying judgment per se.

The qualification of judgment here is primarily a theological one in which forgiveness diverts from condemnation. Judgment saturates Bleak House, from John Jarndyce's refusal to judge to those who are quick to condemn, such as Miss Barbary. Ada's romantic love for Richard paralyses her judgment of him and lack of judgment sometimes enables loyalty, as Lady Dedlock observes to Rosa: "I may trust your attachment if not your judgment" (ch. 48, 573). Judgment is aligned with discernment in the court of Chancery, which, as Watt notes, was not a criminal court but one that dealt with the judgment of fair practice in which the Chancellor was supposed to discern between opposing claims. ${ }^{53}$ The Court of Chancery therefore acted as a bureaucratic and enlarged version of everyday acts of discernment. The fatality of judgment without mercy is personified in Tulkinghorn, whose name draws on the term "tulk," meaning "sound," to invoke the biblical phrase, "sounding horn," the shofar of the Day of Atonement, the blast that closes the fast on Yom Kippur. It is also the sound that causes the walls of Jericho to fall (Joshua 6). Tulkinghorn embodies the sounding horn of judgment and his death heralds an apocalyptic scene that portends Lady Dedlock's end. Despite their seeming incompatibility, Tulkinghorn and Lady Dedlock both represent, in their own way, judgment without mercy. They may seem to be deadly enemies, circling around each other knowingly for the first half the novel, but their 
shared attitude to Lady Dedlock's past is revealed when they finally speak in Tulkinghorn's room in chapter 41 . They are utterly in agreement in judging Lady Dedlock, offering her no mercy and resigning her to a punishment that they both, individually, have judged that she deserves.

Esther is an exemplary figure of judgment, not as a figure of equity, the use of moderation on individual cases, or simply in her Christ-like suspension of condemnation. She is an ideal figure because as well as suspending judgment she, like Queen Esther, passes judgment; she is discerning. Where Queen Esther deflects the force of a deathly law and issues positive laws, so Esther Summerson suspends condemnation in the light of human limitation, but adheres to an ideal of justice that demands the enacting of judgment. Whilst Esther refuses to condemn her mother, she does not denounce judgment like John Jarndyce. To disavow judgment entirely is dangerous in Bleak House, as seen in Jarndyce's inability to judge or contain the harmful Skimpole. Judgment takes on positive form in Esther who demonstrates a quick and witty discernment, sifting the characters around her and treating them in ways that protect herself and others. Esther Summerson imitates Queen Esther in her suspending of judgment that enables her to refuse the ignominy that her godmother and society sets on her and through which she is a positive, redemptive force. Her imitation of Queen Esther's acts of judgment means she is not a passive, selfdenying figure who exists merely for the benefit of others, as she is often understood. ${ }^{54}$ Instead, she demonstrates a remarkably discerning attitude towards those around her.

From her visit to Mrs Jellyby, in which she first exhibits a discernment that Jarndyce delegates to her, Esther scrutinizes people's motivations and actions. She embodies the theological complexity of a figure who simultaneously recognises law's claims, meeting the 
demands of justice, accepts her human inability to enact condemnation, but adjudicates and discerns. Judgment is not an evil to be eradicated, as demonstrated in the story of the woman taken in adultery.

The novel as a whole pre-empts Esther's positive acts of judgments in presenting judgment as a pre-requisite for justice. Invoked, as discussed, through the references to Queen Esther and John 8, it is also rather unusually supported in the novel's references to a biblical text that more obviously inspires a fear of judgment, Revelation's apocalyptic vision of the end of the world. Miss Flite's repeated references to the apocalypse are not merely the exaggerations of a self-admittedly mad woman, but her specific invocation of the "Sixth Seal" (ch. 3. 34; 5. 48, 54), in her ongoing expectation of "a judgment shortly" (ch. 5. 53), links a lack or a delaying of judgment to suffering and its concomitant, justice. The reference to the sixth seal would undoubtedly have a very specific meaning for an audience steeped in the Book of Revelation's signs and symbols. ${ }^{5}$ The apocalypse may end in a single Day of Judgment, but in Revelation 6 we find the gradual stages enacted through the unsealing of scrolls. Miss Flite's call for the breaking of the sixth seal means she positions herself and the Court of Chancery in the time of the fifth seal, a time of anguish for those waiting for judgment. People are suffering for their "testimony" and cry out: "How long, $\mathrm{O}$ Lord, holy and true, dost thou not judge and avenge our blood on them that dwell on the earth?" (Rev 6.10) Like the wards in Jarndyce, these people wait for a justice that only comes with the breaking of the sixth seal and the "great day of his wrath" (6.17). The Day of Judgment is simultaneously a day of terror and of relief. It provokes universal fear in which all people, from "the kings of the earth" to "every bondman, and every free man" (6. 15), attempt to hide from God's wrath. These voices also reveal that it is only on the Day of 
Judgment that judgment and justice coincide. By invoking the sixth seal, Miss Flite invokes a utopic day of judgment that exposes the limitations of Chancery's justice. While the Day of Judgment brings about pure justice at the end of the world, the Chancery case can only offer a human, flawed, judgment.

The novel's exploration of judgment, then, presents it as a necessary aspect of virtuous life. Esther is often read as passive, perhaps because her quiet irony and subtlety underplay her ongoing judgments. With Mr Bucket for example, she wittily replies to his description of Skimpole:

"Harold. Yes. He’s a queer bird is Harold," said Mr. Bucket, eyeing me with great expression.

"He's a singular character," said I.

"No idea of money", observed Mr Bucket. - "He takes it though!”

I involuntarily returned for answer, that I perceived Mr Bucket knew him. (ch. 57, 681)

Both characters barely articulate their opinions and yet their judgment is cutting. Esther and Inspector Bucket are alike, then, in their exemplary perception that nonetheless desists from condemnation. They echo Dickens's aspirations in his declared aversion from hurting the man that Skimpole's character is based on: "I have no right to give Hunt pain."56 Cruelty is to be avoided, and judgment may well be flawed, yet it must be pursued with a necessary caution to avoid the havoc caused by characters like Skimpole.

Refusing to condemn, then, does not necessitate a lack of judgment. Mercy does not negate law but reveals that law is merely a boundary-maintaining force. Law is not rejected in Bleak House: as in John 8, there is no question of the fallen woman's guilt. As we would 
expect from a mid-Victorian novel, actions of adultery, lying and deception in Bleak House are not sanctioned, but the law has done its work in outlining boundaries of behaviour and revealing transgressions. In the case of Bleak House, Dickens does not question that Lady Dedlock has broken some kind of law (whether her fall or her rejection of Hawdon). Dickens questions only the move towards punishment or the more lasting ontological category of condemnation.

Indeed, Lady Dedlock's self-condemnation and death are revealed as tragic through the invocation of the story of the prodigal son. George Rouncewell's return to his mother coincides with Sir Leicester's waiting for Lady Dedlock, and he is the "son come home." In the Charles Dickens Edition, "The Prodigal Son" is the running title given to Mrs Rouncewell's visit to her son in prison in chapter 15, demonstrating a mercy enacted through the wronged party's movement towards the transgressor. ${ }^{57}$ The phrases used in relation to George by Sir Leicester, when he awaits Lady Dedlock's return, invoke the parables of the lost coin, the lost sheep and the prodigal son from Luke 15: "this discovery of some one lost, this return of some one so long gone." These celebrations of the return of something valued are embodied in George's return, to which Sir Leicester is drawn as "strong confirmation of his hopes" that Lady Dedlock also will return to be welcomed by him. The narrative parallel pushes for readerly expectation of a reconciliation whose failure is thereby felt as a loss.

The suspension of condemnation is certainly celebrated in Bleak House. It is Sir Leicester's refusal to condemn his wife that turns this hitherto dislikeable character into an admirable one: "His noble earnestness, his fidelity, his gallant shielding of her, his generous conquest of his own wrong and his own pride for her sake, are simply honourable, manly 
and true." (ch. 58, 828) Esther Summerson is like Sir Leicester in her refusal to condemn Lady Dedlock. But it is Esther's simultaneous passing of judgments that enables her not merely to be a sacrificial moderator of others' lives (as Sir Leicester becomes), but to form the boundaries and connections that enrich her life. The passing of judgment is an act towards others but it is also an act of self-scripting: setting boundaries for the valued self in relation to others' behaviour. Dickens's depiction of an Esther who writes her own narrative reflects the biblical Esther who "wrote with all authority" (9.29) an edict that inaugurates the Purim celebration of redemption. At a time when women's testimonies were lacking in authority, Dickens draws on a Queen Esther who is an authoritative legislator to confer on his protagonist a legislative authority and identity as a writer. In the Book of Esther the written law kills but it also brings life when penned by the hand of Queen Esther. Esther Summerson asserts judgment both in her emulation of Queen Esther's law making and in the act of writing itself. Writing therefore represents an act of self-sovereignty so that Esther Summerson, as writer, embodies what Amanda Anderson sees as incompatible with Victorian understandings of the fallen woman: the "autonomy and coherence of the normative masculine subject." 58

Recognising Esther as a figure who suspends and passes judgment provides a more invigorating way of reading this oft disparaged character. Esther Summerson is a writerly figure, observant and discerning, quietly poking fun at those around her without cruelty. She demonstrates remarkably active discernment by metamorphosing her godmother's reprimands into a life-enabling task. Her godmother admonishes her: "Submission, selfdenial, diligent work, are the preparations for a life begun with such a shadow on it" (ch. 3, 19). Esther converts these bourgeois, Christian values of submission, self-denial and 
diligent work to a vow to be "industrious, contented, and kind-hearted" (ch. 3, 20).

Although soaked in Victorian ideologies of moral virtue, these three qualities are a world apart from her godmother's life-denying and life-destroying path. To be contented is to expect and embrace joy. Instead of subsuming herself within the identity of others, Esther prioritizes pleasure: her own in her aspiration to contentment and others' through kindheartedness.

Dickens's investigation of judgment is pointed directly at society's seemingly unchristian attitude towards the fallen woman and is deliberately provocative, as revealed in a cryptic comment he made whilst writing Bleak House, in which he expresses a hope to provoke judgment in his readers: "see if we don't raise the (East) wind!", the East wind being, of course, Jarndyce's symbol for unease over judging others. ${ }^{59}$ The complex network of biblical references in Bleak House reveals something of Dickens's engagement with theologies of judgment and forgiveness, demonstrating not so much a specific sectarian position, but evidence of a complex understanding of theological issues. Yet, what is most apparent is the socially concrete outworking of these theologies: they are a pragmatic response that challenges rejection of the fallen woman and provokes reflection on what appropriate acts of judgment might look like. Whilst attacking those who condemn the sexually fallen, Dickens avoids a chaotic relativism by simultaneously demonstrating the necessity of enacting a legitimate and ongoing discernment in everyday life.

For Dickens then, it seems that it is not enough that readers do not condemn Esther for the "shame" of her mother or her birth. Instead the novel presents the importance of refusing negative forms of judgment and the positive enacting of good forms of judgment. In her simultaneous refusal and willingness to judge, Esther Summerson takes up the 
mantle of her biblical namesake. Whilst dependent on a framework of New Testament theologies of judgment, justice, law and grace, Dickens seems to turn to the Old Testament story of Esther for its flesh-and-blood character that he could place in his own story. His invocation of Esther as a fallen woman chimes with other novelists' recognition of this Old Testament character as promissory for interrogating prejudices about female sexual behaviour. Drawing on existing associations and connotations of Esther as deliverer and sexually problematic, Dickens produces a complex and nuanced Esther in Bleak House through her ability to accumulate both the significance of Jesus' refusal to condemn the fallen woman in John 8 and Revelation 6's promise of good judgment.

\section{BIBLIOGRAPHY}

Aidé, Charles Hamilton. "The Mystery of the Moated Schloss". All the Year Round, vol. 1, magazine 11 (1869): 253-257.

Anderson, Amanda. Tainted Souls and Painted Faces: The Rhetoric of Fallenness in Victorian Culture. Ithaca, NY: Cornell University Press, 1993.

William Axton. "Esther's Nicknames: A Study in Relevance”. The Dickensian 62 (1966).

Bakhtin, Mikhail. "Discourse in the Novel”. The Dialogic Imagination: Four Essays. Trans. Michael Holquist and Caryl Emerson. Austin: University of Texas Press, 1981.

Beal. Timothy K. The Book of Hiding: Gender, Ethnicity, Annihilation and Esther. Biblical Limits. London: Routledge, 1997.

Bickerman, Elias. Four Strange Books of the Bible: Jonah, Daniel, Koheleth and Esther. New York: Schocken, 1967. 
Bump, Jerome. "The Victorian Radicals: Time, Typology and Ontology in Hopkins, Pusey and Müller", in Victorian Religious Discourse: New Directions in Criticism. Basingstoke: Palgrave Macmillan, 2004.

Carpenter, Mary and George P. Landow. "Ambiguous Revelations: The Apocalypse in Victorian Literature". The Apocalypse in English Renaissance Thought and Literature. Ed. C. A. Patrides and Joseph A. Wittreich. Manchester University Press, 1984: 299-322. Carruthers, Jo. Esther Through the Centuries. Oxford: Blackwell, 2008.

Carson, Alexander. History of Providence as Unfolded in the Book of Esther. $3^{\text {rd }}$ ed. Dublin, 1835.

Colledge, Gary. Dickens, Christianity and 'The Life of Our Lord: Humble Veneration. London: Routledge, 2014.

Colon, Susan. Victorian Parables. London: Continuum, 2012.

Dickens, Charles. Bleak House. Ed. George Ford and Sylvere Mood. London and New York: Norton, 1977.

----- The Life of Our Lord. London: Associated Newspapers Ltd, 1934.

Foucault, Michel. The History of Sexuality, Volume One: An Introduction. London, 1976.

Gaskell, Elizabeth. Household Words vol. 4, Magazine 103 (1852): 588-597 (p. 594).

-----Cranford. London, 1851.

---- Mary Barton. 1848. Ed. Thomas Recchio. London and New York: Norton, 2008.

Hara, Eilichi. "Bleak House and the Reign of Metaphor". Poetica 7 (1994): 36.

Hardy, Thomas. Jude the Obscure. 1895. New York: Norton, 2016.

Hawthorne, Nathaniel. The Scarlet Letter. Ed. Brian Harding. Oxford: Oxford University Press, 1990. 
Henry, Matthew. Matthew Henry's Commentary on the Whole Bible: Complete and Unabridged. Peabody, MA: Hendickson, 2008.

Hillis Miller, J. Tropes, Parables, Performatives: Essays on Twentieth Century Literature. Hertfordshire: Harvester Wheatsheaf, 1991.

Kraus, Carolyn. “A Gentleman’s Agreement: Female Illegitimacy in Nineteenth-Century Male-Authored Fiction". Journal of Research in Gender Studies 1, no. 2 (2011): 73-94.

Lai, Shu-Fang, “Fact or Fancy: What Can We Learn about Dickens from His Periodicals 'Household Words' and 'All the Year Round'?” Victorian Periodicals Review 34.1 (2001): 41-53.

Landow, George, Victorian Types, Victorian Shadows: Biblical Typology in Victorian Literature, Art and Thought. London: Routledge \& Kegan Paul, 1980.

LaPorte, Charles. Victorian Poets and the Changing Bible. Charlottesville: University of Virginia Press, 2011.

Larson, Janet L. “The Battle of Biblical Books in Esther's Narrative”. Nineteenth-Century Fiction 38, no. 2 (1983): 131-160.

Lawson, George. Discourses on the Whole Book of Esther [...]. Edinburgh, 1804.

Lennartz, Norbert. "Introduction". Texts, Contexts and Intertextuality: Dickens as a Reader. Ed. Norbert Lennartz and Dieter Koch. Gottingen: V\& R Unipress, 2014.

Lettmaier, Saskie. Broken Engagements: The Action for Break of Promise of Marriage and the Feminine Ideal, 1800-1940. Oxford: Oxford UP, 2010.

Lewis, Linda M. Dickens, His Parables and His Reader. Columbia and London: University of Missouri Press, 2011.

M'Crie, Thomas. Lectures on the Book of Esther. Edinburgh, 1838. 
Melvill, Henry. “The Sleepless Night”. Sermons. Ed. Right Rev. P.M’Ilvaine . New York:

Standford and Swords, 1850. II, 51-60.

Oulton, Carolyn W. de la L., Literature and Religion in Mid-Victorian England. Basingstoke: Palgrave Macmillan, 2003.

Preston, Shale. 'Esther Summerson's Estate: The Queer, Quasi-Monarchal Line of Beauty, Family and Inheritance in Bleak House". Queer Victorian Families: Curious Relations in Literature. Ed. Duc Dau and Shale Preston. New York: Routledge, 2015. 36-56.

Ragussis, Michael. “The Ghostly Signs of Bleak House’. Nineteenth-Century Fiction 34 no. 3 (1979): 253-80.

Schor, Hilary M. Dickens and the Daughter of the House. Cambridge: Cambridge University Press, 2000.

Scott, Thomas. The Holy Bible containing the Old and New Testaments: With Explanatory Notes, Practical Observations, and Copious Marginal References. 6 volumes. London: 1825.

Scott, Walter. The Heart of Midlothian. Oxford: Oxford University Press, 1982.

Walder, Dennis. Dickens and Religion. 1981. London: Routledge, 2007.

Watt, Gary. "The Equity of Esther Summerson". Law and Humanities. 3, no. 1 (2009): 45-69.

Welsh, Alexander. Dickens Redressed: The Art of Bleak House and Hard Times. New Haven and London: Yale University Press, 2000.

Whyte, Alexander. Bible Characters: Ahithophel to Nehemiah. Edinburgh and London, 1896.

\footnotetext{
${ }^{1}$ Most notably, see Colon, Victorian Parables, ch.5, and Walder, Dickens and Religion.

${ }^{2}$ Letter to Rev. D. Macrae, cited in Walder, Dickens and Religion, 1.

${ }^{3}$ On nineteenth-century reception of Esther see Carruthers, Esther Through the Centuries, 17-20.

4 "Memory at Cranford". For another significant yet brief reference, see James White's "Daisy Hope", Household Words XII, magazine 299 (1855):461-469 (p. 463).
} 
${ }^{5}$ On the limitations of our "conclusions about Dickens and his periodicals", see Shu-Fang Lai, "Fact or Fancy", 50.

${ }^{6}$ See "Esther's Nicknames", 159; Larson, "The Battle of Biblical Books"; Watt, "The Equity of Esther

Summerson" and Preston, "Esther Summerson's Estate". Bleak House, ch. 36, 454-5, hereafter cited by chapter and page number.

${ }^{7}$ Lettmaier, Broken Engagements, 159. Notable examples include Welsh, Dickens Redressed, 36; Schor, Dickens and the Daughter of the House, 105; and Lewis, Dickens, His Parables and His Reader, 139.

${ }^{8}$ Walder, Dickens and Religion, xiii.

${ }^{9}$ See Hara, "Bleak House and the Reign of Metaphor", 36.

${ }^{10}$ See Bump, 'The Victorian Radicals", 31.

${ }^{11}$ Watt, "The Equity of Esther Summerson", 47.

12 Ibid., 52.

13 Ibid., 51.

${ }^{14}$ Larson, "The Battle of Biblical Books", 145.

${ }^{15}$ LaPorte, Victorian Poets and the Changing Bible, 70.

${ }^{16}$ Hardy, Jude, book 4, ch. 1.

${ }^{17}$ Lennartz, "Introduction", 16.

${ }^{18}$ Hillis Miller, Tropes, Parables, Performatives, 135.

${ }^{19}$ Bakhtin, "Discourse in the Novel", 432.

20 Ibid., 277.

21 Ibid.

${ }^{22}$ Esther and Hester are interchangeable spellings so that the Coverdale Bible, for example, names the book Hester.

${ }^{23}$ Poets also drew on Esther, notably Robert Browning in The Ring and the Book and Christina Rossetti in "Monna Innominata". I focus on the novel form because it engages with Esther as a bildungsroman figure.

${ }^{24}$ See Bickerman, Four Strange Books of the Bible and Beal, The Book of Hiding.

${ }^{25}$ Henry Melvill, chaplain to Queen Victoria, articulates a common response to God's absence: "Now that the whole is over, we can clearly trace the hand of God: but, whilst he matter was in progress, we might have discerned nothing but ordinary and every-day events, such as afforded no sign of the interference of Deity", Sermons.

${ }^{26}$ Carruthers, Esther Through the Centuries, 8-9.

27 Beal labels the Book of Esther a "wilderness" in The Book of Hiding, 60.

${ }^{28} \mathrm{M}$ 'Crie, Lectures on the Book of Esther, 45, 50.

${ }^{29}$ Gaskell, Cranford, 100.

${ }^{30}$ Brian Harding cites Sacvan Berkovitch in his note on Queen Esther in the Oxford edition of The Scarlet Letter, 274.

${ }^{31}$ See Carruthers, Esther Through the Centuries, 126-7.

32 Lawson, Discourses on the Whole Book of Esther, 113, 133, 180.

33 Ibid. 225.

${ }^{34}$ Scott, The Holy Bible, Notes on V. 13, 14.

${ }^{35} \mathrm{Scott}$, The Heart of Midlothian, ch. 27, 266, hereafter cited by chapter and page number.

${ }^{36}$ Larson, "The Battle of Biblical Books", 143.

${ }^{37}$ Whyte, Bible Characters, 195.

38 Carson, History of Providence, 21, 24.

${ }^{39} \mathrm{Scott}$, The Holy Bible, notes on V. 8-10.

${ }^{40} \mathrm{M}$ 'Crie, Lectures on the Book of Esther, 45, 50, 51.

${ }^{41}$ Gaskell, Mary Barton, ch. 10, 111, 112.

42 Ibid. 112.

${ }^{43}$ Kraus, "A Gentleman's Agreement", 79, 82.

44 Ibid. 78.

${ }^{45}$ On Dickens's objection to inherited guilt, see Carolyn W. de la L. Oulton, Literature and Religion in MidVictorian England, ch. 3 and especially 108.

${ }^{46}$ Dickens, The Life of Our Lord, 60. 
${ }^{47}$ On the centrality of forgiveness to The Life of Our Lord see Colledge, Dickens, Christianity and "The Life of Our Lord", 89. On forgiveness in Dickens's work more generally, see Oulton, Literature and Religion in MidVictorian England. Neither work engages with the issue of law.

${ }^{48}$ Scott, The Holy Bible, notes on John 8, v. 3-11.

${ }^{49}$ Clarke, The Gospels Harmonized, 265.

50 Watt, "The Equity of Esther Summerson", 42.

51 Ibid. 47.

52 Ragussis briefly notes that Queen Esther "reverses Haman's law of the dead letters in a striking prefiguration of the New Testament", but does not recognize the dual aspect of Esther's suspension and making of law or its connection to the fallen woman, "The Ghostly Signs of Bleak House", 265.

53 Watt, "The Equity of Esther Summerson", 46.

${ }^{54}$ Oulton's examination of Esther Summerson and judgment in Literature and Religion in Mid-Victorian England continues an interpretation of her as "irreparably damaged" (102) and "guilty of false humility" (137).

55 See Carpenter and Landow, "Ambiguous Revelations".

${ }^{56}$ Letter to John Foster, March 18, 1852, in Dickens, Bleak House, 887. Dickens argues Skimpole draws only on Leigh Hunt's positive traits, not his "vices", see "A Literary Life", All the Year Round VII, (12 ${ }^{\text {th }}$ April 1862), 115119 (117).

57 The "Charles Dickens Edition" is the last Dickens himself edited, produced by Chapman and Hall in 1867. See Dickens, Bleak House, 802.

${ }^{58}$ Anderson, Tainted Souls and Painted Faces, 1.

${ }^{59}$ Dickens, Bleak House, 885. 